\title{
PENERAPAN ALGORITMA BOYER MOORE DALAM PERANCANGAN KAMUS ISTILAH PERTANIAN BERBASIS ANDROID
}

\author{
Fitriani Br. Manurung1, Nelly Astuti Hasibuan², Natalia Silalahi \\ 1,2Program Studi Teknologi Informatika STMIK Budi Darma,Medan, Indonesia \\ Email: ${ }^{1}$ fitrimanurung3@gmail.com
}

\begin{abstract}
Abstrak
Dunia yang semakin berkembang pesat membuat munculnya istilah-istilah baru yang tidak biasa dalam masyarakat terkhusus dalam bidang pertanian,maka dari itu dengan didukungnya fitur canggih maka dirancanglah sebuah kamus digital yang berisi istilahdan maknanya.Kamus istilah pertanian merupakan kamus berisikan istilah pertanian yang sulit dimengerti masyarakat serta maknanya yakni berbentuk digital dalam sebuah smartphone yang dapat digunakan dimana saja dan kapan saja hanya dalam segenggam,dalam merancang sebuah kamus dibutuhkan sebuah algoritma yang dapat mendukung yaitu algoritma boyer moore.Algoritma boyer moore merupakan salah satu algoritma yang dapat digunakan dalam pencarian kata pada aplikasi kamus,pencarian string dalam algoritma ini dapat dilakukan dari kanan.algoritma boyer moore dikenal sebagai algoritma yang tepat dalam mempermudah pencarian string.
\end{abstract}

Kata Kunci: Perancangan, Kamus Istilah Pertanian, Algoritma Boyer Moore

\begin{abstract}
The process of selecting the North Sumatra Ambassador Language Finalists at the North Sumatra Language Hall is still subjective in that the assessment may not be based on established criteria or without looking objectively so that the selection process is carried out less precisely and the resulting decision is less satisfactory for the participants of the Ambassador Finalists North Sumatra Language. In this study, the authors used a decision support system with the Promethee II method to find the value of weights and criteria, and to find the final score or to find the finalist ranking of the North Sumatra Language Ambassador. Thus the Decision Support System is needed in order to help the North Sumatra Language Office in determining the Finalists of the North Sumatra Language Ambassador. To overcome these problems, it is necessary to build a decision support system application for the selection of North Sumatra Language Ambassador Finalists using the Promethee II method so that it can help and facilitate the North Sumatra Language Hall in making a decision to choose the North Sumatra Language Ambassador and the resulting decision is satisfactory.
\end{abstract}

Keywords: Decision Support System, Language Ambassadors, Promethee Method ii

\section{PENDAhUluaN}

Dunia teknologi merupakan dunia serba digital, yang dapat melakukan apa saja dengan kemudahan yang disuguhkan. Demikian halnya dengan perkembang telepon seluler (Smartphone) juga semakin canggih dan di minati,dikarenakan dapat memudahkan pengguna dalam hampir segala hal.Smartphone juga menyuguhkan fitur-fitur yang memanjakan pengguna,juga sudah memiliki beberapa sistem operasi open source,dan android yang saat ini berkembang dengan cepat.Sehingga pengguna dapat membuat aplikasi sendiri yakni aplikasi menawarkan pengguna menemukan sumber yang secara gratis,contohnya yaitu aplikasi kamus. Kamus merupakan sejenis buku yang dapat membantu dalam hal menguraikan atau menjelaskan pengertian dari sebuah kata.Namun di jaman sekarang dalam genggaman juga sudah tersedia kamus,yakni kamus digital yang dapat dilihat dari smartphone[1].Fungsi kamus juga dapat mengetahui adanya kata baru yang muncul,selain itu kamus juga memiliki pedoman sebutan asal usul (etimologi) suatu kata dan contoh penggunaan sebuah kata.Kamus terbagi dalam beberapa jenis seperti kamus bahasa,kamus istilah dan kamus lainnya. Kamus istilah merupakan kamus yang berisi kumpulan istilah dari suatu bidang dan makna dari istilah tersebut.Penelitian ini akan membahas kamus istilah pertanian.

Pada ruang lingkup pertanian memiliki banyak istilah-istilah yang tidak di mengerti oleh banyak orang.Khususnya dunia pendidikan bidang pertanian harus memahami istilah-istilah pertanian serta artinya,dikarenakan terlalu banyak istilah membuat masyarakat bahkan pada bidang pertanian itu sendiri sulit untuk memahami.Untuk itu diperlukan adanya kamus istilah pertanian yang berisikan istilah pertanian serta arti ataupun artinya,yang nantinya dapat digunakan oleh pengguna untuk lebih mudah memahami arti pada istilah-istilah pertanian.Selain itu untuk mempermudah pencarian kata dalam kamus tersebut maka dibutuhkan sebuah algoritma yaitu algoritma string matching.Algoritma string matching yang digunakan dalam penelitian ini adalah algoritma boyer moore. 
Algoritma boyer moore merupakan salah satu algoritma yang dapat digunakan dalam pencarian kata pada aplikasi kamus,algoritma boyer moore dikenal sebagai algoritma yang tepat dalam mempermudah pencarian string.Algoritma Boyer Moore adalah salah satu algoritma untuk mencari suatu string di dalam teks, dibuat oleh R.M Boyer dan J.S Moore.Algoritma Boyer Moore melakukan perbandingan dimulai dari kanan ke kiri,tetapi pergeseran window tetap dari kiri ke kanan.Jika terjadi kecocokkan maka dilakukan perbandingan karakter teks dan karakter pola yang sebelumnya,yaitu dengan sama-sama mengurangi indeks teks dan pola masing-masing sebanyak satu.Dengan mengunakan algoritma ini,secara rata-rata proses pencarian akan menjadi lebih cepat jika dibandingkan dengan algoritma lainnya[2]

\section{TEORITIS}

\subsection{String Matching}

String matching atau pencocokan string adalah suatu metode yang digunakan untuk menemukan suatu keakuratan atau hasil dari satu atau beberapa pola teks yang diberikan. String Matching adalah proses pencarian semua kemunculan query yang selanjutnya disebut pattern ke dalam string lebih panjang atau teks[1].

String Matching dirumuskan sebagai berikut:

$\mathrm{x}=\mathrm{x}[0 \ldots \mathrm{m}-1]$

$\mathrm{y}=\mathrm{y}[0 \ldots \mathrm{n}-1]$

Dimana:

$\mathrm{x} \quad=$ pattern

$\mathrm{m} \quad$ = panjang pattern

$\mathrm{y}=$ teks

$\mathrm{n} \quad$ = panjang teks

Kedua string terdiri dari sekumpulan karakter yang disebut alfabet yang dilambangkan dengan $\sum$ (sigma) dan mempunyai ukuran $\sigma$ (tao). String matching dibagi menjadi dua, yakni exact matching dan heuristic atau statistical matching.

\subsection{Algoritma Boyer Moore}

Algoritma Boyer-Moore adalah salah satu algoritma pencarian string yang dipublikasikan oleh Robert S. Boyer dan J. Strother Moore pada tahun1977. Algoritmaini dianggap sebagai algoritma yang paling efisien pada aplikasi yang umum tidak seperti algoritma pencarian string lain, algoritma Boyer-Moore mulai mencocokkan karakter dari sebelah kanan pattern. Ide dibalik algoritma ini adalah bahwa dengan memulai pencocokkan karakter dari kanan, dan bukan dari kiri, maka akan lebih banyak informasi yang didapat[3]. adalah:

Secara sistematis, langkah-langkah yang dilakukan algoritma Boyer-Moore pada saat mencocokkan string

1. Algoritma Boyer-Moore mulai mencocokkan pattern pada awal teks.

2. Dari kanan ke kiri, algoritma ini akan mencocokkan karakter per karakter pattern dengan karakter di teks yang bersesuaian, sampai salah satu kondisi berikut dipenuhi:

a. Karakter di pattern dan di teks yang dibandingkan tidak cocok (mismatch).

b. Semua karakter di pattern cocok. Kemudian algoritma akan memberitahukan penemuan di posisi ini.

3. Algoritma kemudian menggeser pattern dengan memaksimalkan nilai penggeseran good-suffix dan penggeseran bad-character, lalu mengulangi langkah 2 sampai pattern berada di ujung teks.

\subsection{Kamus Istilah Pertanian}

Kamus istilah pertanian merupakan buku yang berisikan tentang bahasa-bahasa asing yang sulit di mengerti beserta isinya. Dibawah ini merupakan beberapa istilah serta makna dari istilah pertanian[4].

Tabel 1. Istilah Pertanian

\begin{tabular}{|c|c|c|}
\hline No & $\begin{array}{c}\text { Istilah } \\
\text { Pertanian }\end{array}$ & Arti \\
\hline 1 & Ajir & $\begin{array}{l}\text { Batang yang berfungsi sebagai penyangga atau tempat bersandar atau merambat tanaman atau } \\
\text { bias juga berfungsi sebagai penanda }\end{array}$ \\
\hline 2 & Bakterisida & Obat untuk membunuh hama tanaman yang disebabkan oleh bakteri. \\
\hline 3 & Ale & $\begin{array}{l}\text { Senyawa Kimia yang dikeluarkan tumbuhan untuk menghambat pertumbuhan atau bahkan } \\
\text { membunuh tumbuhan lain }\end{array}$ \\
\hline 4 & Anak Cabang & Tunas baru pada cabang \\
\hline
\end{tabular}




\section{ANALISA DAN PEMBAHASAN}

\subsection{Analisa}

Kamus merupakan bahasa-bahaa yang memiliki arti yang biasanya berbentuk sebuah buku. Kamus istilah pertanian merupakan beberapa bahasa-bahasa pertanian yang terkadang sulit dimengerti masyarakat atau bahkan bidang pertanian itu sendiri, seperti setiap hari mungkin para petani atau mahasiswa pertanian sering menyebutkan istilah pertanian namun tidak mengerti arti sesungguhnya dan itu bisa mengakibatkan kesalahan yang fatal, Maka dari itu penulis merancang kamus istilah pertanian berbasis android dengan tujuan utama ialah untuk memperbanyak kosakata bagi penggunanya dan membantu ,e,persingkat waktu tanpa harus membuka kamus buku. Kamus ini ialah kamus berbasis android yang dapat diakses kapan saja dan dimana saja, kamus ini juga sebagiannya adalah bahasa asing namun diterjemahkan kedalam bahasa Indonesia, jadi jika pengguna ingin mengerti arti sebuah kata dari istilah pertanian tersebut, maka pengguna boleh menggunakan aplikasi tersebut lalu mengetikkan kata yang akan dicari artinya, lalu akan muncul penjelasan dari istilah tersebut.

Kamus istilah pertanian ini adalah pencocokan kata, maka didalam aplikasi ini memiliki penyimpanan data (database) kata yang benar, sehingga apabila pengguna mengetik kata yang benar atau sesuai dengan database yang ada, maka akan muncul kotak dialog penjelasan dari istilah tersebut, namun jika kata yang akan dicari tidak sesuai dengan database yang ada maka pengguna harus mengetik ulang kata yang benar.

Dalam melakukan pencarian pada aplikasi kamus istilah pertanian, aplikasi ini menggunakan metode String Matching. Dalam menentukan pattern yang akan dikembangkan, metode ini akan mencocokan kata pada board dengan kata kunci. Berikut gambar dari langkah-langkah metode String Matching pada aplikasi Kamus Istilah Pertanian.

\subsection{Pembahasan}

Implementasi algoritma boyer moore pada penelitian ini yaitu untuk mendapatkan hasil pencocokan kata pada Kamus Istilah Pertanian. Pencocokan pada Kamus Istilah Pertanian yang akan dilakukan pada penelitian ini adalah pencarian karakter pattern pada text.

Contoh 1 : Pencarian 1 kata

Text : BAKTERISIDA

Pattern : SIDA

Tabel 2. Nilai $\mathrm{OH}$ dan MH pada pattern

\begin{tabular}{lllll}
\hline Index & 0 & 1 & 2 & 3 \\
\hline Pattern & $\mathrm{S}$ & $\mathrm{I}$ & $\mathrm{D}$ & $\mathrm{A}$ \\
OH & 3 & 2 & 1 & 0 \\
$M H$ & 4 & 4 & 4 & 4 \\
\hline
\end{tabular}

1. Cara mencari OH yaitu : "Length - 1 - Indeks"

$\mathrm{S}=\mathrm{k} 1=4-1-0=3$

$\mathrm{I}=\mathrm{k} 2=4-1-1=2$

$\mathrm{D}=\mathrm{k} 3=4-1-2=1$

$\mathrm{A}=\mathrm{k} 4=4-1-3=0$

2. Cara mencari $\mathrm{MH}$ yaitu nilainya sama dengan jumlah pattern yaitu 4 , namun jika $\mathrm{OH}$ nya ada yang bernilai 0 , maka nilai $\mathrm{MH}$ nya 1 .

Tahapan pencocokan string untuk pencarian karakter pattern SIDA pada text BAKTERISIDA adalah sebagai berikut ini :

1. Tahap Pertama

Pada tahap pertama, pencocokan string pattern dimulai dengan deretan string text yang pertama "SIDA “.

Tabel 3.2 Processing Tahap Pertama

\begin{tabular}{ccccccccccccc}
\hline Posisi Teks & 1 & 2 & 3 & 4 & 5 & 6 & 7 & 8 & 9 & 10 & 11 \\
\hline Teks & B & A & K & T & E & R & I & S & I & D & A \\
Pattern & S & I & D & A & & & & & & &
\end{tabular}

Pada tahap ini karakter "T" dengan "A" tidak sama, dan karakter $\mathrm{N}$ tidak memiliki kesamaan dengan karakter pattern yang lainnya, sehingga bergeser sebanyak jumlah karakter pattern yaitu 4 langkah. 
2. Tahap Kedua

Pada tahap kedua yaitu pencocokan string SIDA dengan deretan text "ERIS “.

\begin{tabular}{ccccccccccccc} 
& \multicolumn{10}{c}{ Tabel 3.3 Processing Tahap Kedua } \\
\hline Posisi Teks & 1 & 2 & 3 & 4 & 5 & 6 & 7 & 8 & 9 & 10 & 11 \\
& & & & & & & & & & & \\
\hline Teks & B & A & K & T & E & R & I & S & I & D & A \\
Pattern & & & & & S & I & D & A & & & \\
& & & & & & &
\end{tabular}

Pada pergeseran Ke-2 karakter "S" pada pattern tidak cocok dengan karakter "A" pada teks, maka pergeseran selanjutnya berdasarkan nilai dari 577able OH. Pada 577able OH karakter "A" terdapat pada 577able, sehingga pergeseran selajutnya adalah sebanyak jumlah karakter "A" pada 577able OH pada yaitu 0, maka ditahap selanjutnya, pattern langsung ke kotak selanjutnya.

3. Tahap Ketiga

Pada tahap ketiga dilakukan pencocokan string pattern dengan deretan string text "SIDA".

\begin{tabular}{ccccccccccccc} 
& \multicolumn{10}{c}{ Tabel 3.4 Processing Tahap Ketiga } \\
\hline Posisi Teks & 1 & 2 & 3 & 4 & 5 & 6 & 7 & 8 & 9 & 10 & 11 \\
& & & & & & & & & & & \\
Teks & B & A & K & T & E & R & I & S & I & D & A \\
Pattern & & & & & & & & S & I & D & A
\end{tabular}

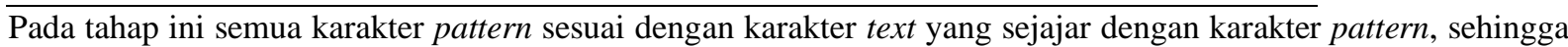
pergeseran karakter pattern berhenti.

\section{KESIMPULAN}

Berdasarkan hasil akhir pemecahan masalah pencarian isi kamus istilah pertanian pada penelitian maka penulis menguraikan beberapa kesimpulan. Adapun kesimpulan-kesimpulan tersebut antara lain sebagai berikut :

1. Proses pencarian istilah pertanian dapat dilakukan dengan melakukan pencocokan string atau dengan menggunakan algoritma string matching

2. Algoritma Boyer Moore dapat diterapkan untuk melakukan pencocokan string pada proses pencarian istilah pertanian dimana pattern yang diinputkan adalah istilah yang akan dicari.

3. Aplikasi kamus istilah pertanian telah selesai dirancang dengan menggunakan editor eclipse juno dan telah dapat dijalankan untuk mencari istilah pertanian.

\section{REFERENCES}

[1] M. Ayu Permatasari Siahaan, "IMPLEMENTASI ALGORITMA BOYER MOORE PADA APLIKASI KAMUS NAMA BAYI BESERTA MAKNANYA BERBASIS ANDROID,” vol. 17, no. 2301-9425, p. 97, 2018.

[2] G. L. G. Citra Puji Lestari, Nelly Astuti Hasibuan, "Perancangan Aplikasi Kamus Istilah Medis Berbasis Android Dengan Algoritma Boyer-Moore," vol. II, no. 2502-6968, p. 28, 2016.

[3] Guidio Leonaerde Ginting, "Penerapan Algoritma Boyer Moore Pada Aplikasi Pengajuan Judul Skripsi Berbasis web," vol. 3, no. 2339-210X, p. 124, 2014.

[4] Team Penyusun Kamus PS, KAMUS PERTANIAN UMUM, I. Cibubur, Jakarta Timur: Penebar Swadaya, anggota Ikapi, 2013.

[5] Y. S. Agung Prayitno, Asahar Johar, "IMPLEMENTASI ALGORITMA TURBO BOYER MOORE PADA APLIKASI KAMUS ISTILAH BIOLOGI BERBASIS ANDROID,” vol. 6, no. 2303-755, p. 15, 2018.

[6] A. Unpam, "KBBI," 2014. .

[7] Dermiyati, SISTEM PERTANIAN ORGANIK BERKELANJUTAN, I. Yogyakarta: plantaxia, 2015.

[8] M. S. dan Werstantia, "Perancangan Aplikasi Pemesanan Catering Berbasis Mobile Android," vol. 1, 2018. 